The University of San Francisco

USF Scholarship: a digital repository @ Gleeson Library |

Geschke Center

School of Education Faculty Research

School of Education

2012

\title{
Cultivating Young Women's Leadership for a Kinder, Braver World
}

A Rorem

Monisha Bajaj

University of San Francisco, mibajaj@usfca.edu

Follow this and additional works at: http://repository.usfca.edu/soe_fac

Part of the Education Commons

\section{Recommended Citation}

Rorem, A. \& M. Bajaj. (2012). “Cultivating Young Women's Leadership for a Kinder, Braver World.” Kinder \& Braver World Project: Research Series. Berkman Center for Internet and Society at Harvard University. http://cyber.law.harvard.edu/node/8094

This Other is brought to you for free and open access by the School of Education at USF Scholarship: a digital repository @ Gleeson Library| Geschke Center. It has been accepted for inclusion in School of Education Faculty Research by an authorized administrator of USF Scholarship: a digital repository@Gleeson Library | Geschke Center. For more information, please contact repository@usfca.edu. 


\title{
Cultivating Young Women's Leadership for a Kinder, Braver World
}

\author{
December 17, 2012
}

Anna Rorem and Dr. Monisha Bajaj*

The Kinder \& Braver World Project: Research Series (danah boyd, John Palfrey, and Dena Sacco, editors)

Brought to you by the Born This Way Foundation \& the Berkman Center for Internet \& Society at Harvard University, and supported by the John D. \& Catherine T. MacArthur Foundation

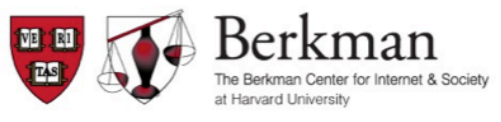

*Anna Rorem is currently pursuing an MPP at University of Virginia's Frank Batten School of Leadership and Public Policy. Monisha Bajaj, Ed.D. is an Associate Professor in the Department of International and Transcultural Studies at Teachers College, Columbia University. Anna Rorem was a summer intern at the Sadie Nash Leadership Project and Monisha Bajaj sits on its Board of Directors. 


\section{INTRODUCTION}

There is not much research exploring leadership development and civic participation among youth, and even less among young women. Policymakers and others seeking to better serve youth in pursuit of a "kinder, braver world" should take into account the research that does exist. This research indicates that youth who engage in service to their communities learn leadership skills through civic action and may be more likely to vote and be civically engaged as adults. Youth who demonstrate leadership skills can, and should, be considered current assets to their communities.

\section{KEY LESSONS FROM EXISTING RESEARCH}

\section{Leadership is the application of ability and agency to exercise authority, which is used to positively influence others.}

Leadership should not be understood as "power over", but instead as "power to..." and "power with..." The product of leadership (e.g., the task accomplished) matters more than the fact that one may have others willing to follow them.

\section{Adults should model positive leadership.}

There are three primary types of effective adult/youth partnerships: facilitation, apprenticeship, and joint work. ${ }^{1}$ The model an organization employs reflects whether it prioritizes process or product, or seeks to balance both.

- Through facilitation, adults provide limited guidance to students; adults' primary role is to create an environment in which youth select their own projects, establish their own deadlines, and lead their own meetings. This approach is most conducive to helping youth build skills such as strategic thinking or planning.

- Apprenticeship balances youth development of leadership skills with emphasis on campaign success. Adults serve as coaches, helping students implement their ideas with more hands-on participation and advice than in facilitation. Typically, this approach works best for organizations that seek to balance leadership development with a specific goal, such as organizing a rally or workshop.

- A joint work model, in which adults and students work collaboratively, may be best for organizations focused primarily on creating a successful campaign. Typically, this kind of partnership imparts the lessons of leadership tacitly, and more through hands-on practice than through mentorship.

\section{There are two primary strategies of leadership.}

\footnotetext{
${ }^{1}$ Kirshner, B. (2008). Guided participation in three youth activism organizations: Facilitation, apprenticeship, and joint work. The Journal of the Learning Sciences, 17(1), 60-101.
} 
- In transformational leadership, the leader initiates a kind of partnership with followers that is based on mutual trust and invites collaboration.

- In contrast, transactional leadership is a more traditional technique that involves setting objectives and responsibilities for followers. With this strategy, the leader appeals to followers' self-interest to inspire cooperation.

\section{Women appear to be particularly effective as transformational leaders.}

Research suggests that women may be more likely to adopt transformational, rather than transactional, leadership styles. In addition, some studies show that women are more effective than men when both apply the same transformational techniques. Other studies suggest that women may be perceived as more effective leaders when they adopt a grouporiented (i.e., transformational), compared to when they employ a task-oriented (i.e., transactional) one. Because leadership interacts so thoroughly with gender, it is helpful to consider leadership development through a gender-specific lens.

\section{WHAT WORKS? TWO CASE STUDIES}

Two studies on leadership programs for young women serve as a basis for recommendations on how to best implement leadership development programs.

\section{Case Study \#1: Sadie Nash Leadership Project}

Sadie Nash Leadership Project (SNLP) is a New York City-based non-profit organization that seeks to develop leadership skills among girls in high school through after-school and summer programs offering academic work and youth-initiated social justice projects. Each year, the organization works with approximately 300 young women in New York City and Newark, New Jersey. Participants are often eligible for free- or reduced-price lunch, attend a public high school, and are primarily young women of color from diverse ethnic and racial backgrounds. Research suggests that, through this project, participants develop multiple definitions of leadership, develop a heightened awareness of self-as-leader, understand diverse responsibilities of leadership, and recognize forces that may work against leadership development, such as social inequalities, stereotypes, or discrimination. Findings suggest that the program encourages leadership development through multiple techniques, including ${ }^{2}$ :

(1) The maintenance of a safe space exclusively for women;

(2) Emphasis on community;

(3) The modeling of female leadership by the adults facilitating and participating in the program; and,

${ }^{2}$ Hoyt, M. A. (2008). Leadership and adolescent girls: A qualitative study of leadership development. American Journal of Community Psychology, 42(3-4), 203-219. 
(4) Group discussions and analyses of status-quo structures of power (including institutionalized oppression) as challenges these low-income young women face as emerging leaders.

\section{Case Study \#2: The Young Women's Leadership Program}

The Young Women's Leadership Program engaged students at three public high schools in a small town in central California consisting of predominantly white (68 percent) and Latina (20 percent) students. ${ }^{3}$ The program met once a week after school for 15 weeks with the goal of enacting a social justice campaign to raise awareness of a youth-chosen issue. A study of this program identified two themes:

(1) Adult guidance is necessary to promote a broad understanding of leadership; and,

(2) A space where young women feel safe, and comfortable expressing themselves, is essential to their empowerment.

\section{RECOMMENDATIONS}

Based on the research and interventions described above, the following recommendations might help those hoping to promote young women's leadership through school-based, afterschool, and co-curricular programs.

\section{Youth organizations should facilitate learning through participatory discussions rather than didactic instruction.}

In organizations devoted to cultivating youth leadership, adults should serve as guides and role models, not instructors. Discussion and collaborative projects should take priority over a traditional classroom setting. For example, SNLP works with young women to raise their awareness of the structural forces of oppression through a course called Power, Identity, and Privilege, and then through youth-led community action projects. Organizations serving young women should actively facilitate youth discussions about the constructions, limits, and possibilities for leadership and youth action. Adults who cultivate this learning environment encourage youth agency while also imparting content.

\section{Youth organizations should encourage diverse leadership styles}

Young women previously exposed only to traditional models of leadership may benefit from seeing a more diverse range of leadership styles. Such styles can, and should, include those that may be perceived as non-traditional, such as "mediator", "supporter", and "respectful

\footnotetext{
3 Information on this organization comes from: Denner, J., Meyer, B., \& Bean, S. (2005). Young women's leadership alliance: Youth-adult partnerships in an all-female after-school program. Journal of Community Psychology, 33(1), 87-100. doi: 10.1002/jcop.20036
} 
dissenter"; young women should be encouraged to exercise a variety of roles. Organizations that model and provide opportunities for different styles of leadership encourage strategic and creative thinking among participants. Furthermore, emphasizing that there are many everyday "leaders", as opposed to a few "Leaders" in formal positions, creates more opportunities for participation.

\section{Young women's leadership programs should draw on leaders that model the constituency served.}

Young women are likely to have a positive understanding of female leadership possibilities if they are exposed to a variety of leadership styles modeled by women. Women are also more likely to see themselves as leaders if they are exposed to many examples of female leaders, both within an organization (e.g., youth workers and program directors) as well as external to it (e.g., guest speakers). Young women may be particularly receptive to counselors or facilitators who are close to them in age; for example, SNLP hires college-aged "deans" for each summer program, who work closely with participants on a daily basis, responding mainly to group social and emotional dynamics. Because most SNLP participants are young women of color, program directors seek to hire a group of female deans that closely resembles the racial and ethnic composition of the participants, making "leadership" appear more attainable and immediate to the young women served.

\section{Youth organizations should incorporate youth as decision-makers.}

Organizations should integrate youth into their organizational management and decisionmaking in order to encourage youth to see themselves as leaders. For example, young women may occupy seats on the board of directors, be asked to participate in a self-study, or conduct interviews of applicants for full-time staff or faculty positions (as done at SNLP). The basis for this recommendation is three-fold: (1) Incorporating youth as decision-makers reminds youth that they are assets to an organization, not just consumers of its services (2) having youth serve in these roles provides yet another opportunity for them to "do" leadership; and (3) youth's unique perspective on the organization may be a source of invaluable feedback and honest assessment.

\section{Organizations should acknowledge the material realities of youths' lives.}

When working with high-school aged youth from low-income families, as is often the case when working in an urban or rural setting, participation in a youth development program may compete with opportunities for employment. In order to encourage participation, organizations must make themselves competitive options. Organizations should acknowledge youths' financial constraints and seek to explicitly demonstrate the value they place on youths' time and engagement by offering incentives for participation, such as stipends, grants, or other resources. In addition to incentives, subsidies for transportation and/or meals may be offered. By placing value on youth's involvement, organizations not only demonstrate the value they place on youth leadership, but also make themselves viable 
alternatives to after-school or summer jobs, thereby encouraging participation and sustained involvement. In addition to promoting youth leadership development, research indicates that ensuring that youth development opportunities are accessible to students from low-income backgrounds may also help in limiting the widening achievement gap in United States.

\section{Youth organizations should deliberately create a safe space for all participants through curriculum, pedagogy, and program design.}

The term "safe space" typically refers to an environment in which individuals feel comfortable expressing opinions, testing new ideas, and voicing concern or confusion, free of judgment. Safe space is critical for youth programs seeking to develop leadership in young women for two reasons. First, youth will be better able to test new notions of leadership, or take on new roles of leadership, in a supportive environment. In addition, a space that is exclusively for young women, as well as accepting of all sexual orientations and gender identities, allows participants to explore the interaction of gender and leadership in an encouraging environment. In order to create safe space, adults could determine a set of requirements; however, the first recommendation, above, suggests that youth and adults can collaboratively construct norms.

These recommendations offer educators, policymakers, and practitioners insights into ways to enhance youth leadership and agency, particularly for young women. Young women's participation and leadership in all spheres of public life can only accelerate our progress towards a kinder and braver world for all people(s).

\section{FURTHER RESOURCES ON YOUTH ACTION AND YOUNG WOMEN'S LEADERSHIP}

- Sadie Nash Leadership Project: http://www.sadienash.org/

- Empowering Young Women to Lead Change Manual (YWCA): http://www.worldywca.org/Resources/YWCA-Publications/Empowering-YoungWomen-to-Lead-Change

- The Teen Guide to Global Action: How to Connect with Others (Near \& Far) to Create Social Change (Barbara A. Lewis)

- Youth Organizing for Community Power Manual (School of Unity and Liberation): http://www.schoolofunityandliberation.org/soul_sec/resources/reshp_manuals.html

- Youth-Adult Partnerships Training Manual (Innovation Center for Community and Youth Development, National 4-H Council, National Network for Youth, \& Youth Leadership Institute): http://www.theinnovationcenter.org/files/YouthAdultPartnerships'TrainingManual.pdf 
- A Guide for Engaging Youth in Leadership and Decision Making in ServiceLearning Programs (Youth Service America):

http://www.servicelearning.org/filemanager/download/7/YVGuide.pdf

\section{REFERENCE LIST}

Denner, J., Meyer, B., \& Bean, S. (2005). Young women's leadership alliance: Youth-adult partnerships in an all-female after-school program. Journal of Community Psychology, 33(1), 87-100. doi: 10.1002/jcop.20036

Hoyt, M. A. (2008). Leadership and adolescent girls: A qualitative study of leadership development. American Journal of Community Psychology, 42(3-4), 203-219.

Kirshner, B. (2008). Guided participation in three youth activism organizations: Facilitation, apprenticeship, and joint work. The Journal of the Learning Sciences, 17(1), 60-101. 